\title{
Bilophila wadsworthia
}

National Cancer Institute

\section{Source}

National Cancer Institute. Bilophila wadsworthia. NCI Thesaurus. Code C86201.

A species of anaerobic, Gram-negative, rod shaped bacteria assigned to the phylum Proteobacteria. This species is nonmotile, non-spore forming, catalase positive, indole and lipase negative, stimulated by bile, reduces nitrate, produces hydrogen sulfide, does not hydrolyze starch or esculin, and most strains are urease positive. B. wadsworthia are pleomorphic rods with swollen ends and is associated with appendicitis. 